IZA DP No. 4676

A Note on Informality in the Labor Market

Melanie Khamis

December 2009 


\title{
A Note on Informality in the Labor Market
}

\author{
Melanie Khamis \\ IZA
}

\section{Discussion Paper No. 4676 \\ December 2009}

\author{
IZA \\ P.O. Box 7240 \\ 53072 Bonn \\ Germany \\ Phone: +49-228-3894-0 \\ Fax: +49-228-3894-180 \\ E-mail: iza@iza.org
}

\begin{abstract}
Any opinions expressed here are those of the author(s) and not those of IZA. Research published in this series may include views on policy, but the institute itself takes no institutional policy positions.

The Institute for the Study of Labor (IZA) in Bonn is a local and virtual international research center and a place of communication between science, politics and business. IZA is an independent nonprofit organization supported by Deutsche Post Foundation. The center is associated with the University of Bonn and offers a stimulating research environment through its international network, workshops and conferences, data service, project support, research visits and doctoral program. IZA engages in (i) original and internationally competitive research in all fields of labor economics, (ii) development of policy concepts, and (iii) dissemination of research results and concepts to the interested public.
\end{abstract}

IZA Discussion Papers often represent preliminary work and are circulated to encourage discussion. Citation of such a paper should account for its provisional character. A revised version may be available directly from the author. 
IZA Discussion Paper No. 4676

December 2009

\section{ABSTRACT}

\section{A Note on Informality in the Labor Market}

This paper provides a detailed analysis of various dimensions of informality in the Mexican labor market. To understand the nature of informality in terms of regulations and compliance, the legalistic view, and in terms of productivity view of the labor market this paper makes an empirical contribution to the debate in the literature on the concept of informality. Questions related to these various concepts, social security and benefits coverage, contractual information, legal status of migrants, the nature of self-employment and job history information are analyzed in terms of their relationship to each other and are also related to individual and household characteristics. This paper finds a substantial overlap between the various concepts, current legal arrangements of social security coverage or contract and also in the individual's job history. In terms of individual characteristics age, education, martial status and scores in the Raven's test, an ability measure, are significant determinants for the various forms of informality, with some degree of variation across the different categories. Overall, a case is made for further studies of household survey data and the implementation of questions relating to different dimensions of informality and their inter-linkages.

JEL Classification: $\quad$ J40, 017

Keywords: informality, social security, contracts, illegal migration, self-employment, job history, Mexico

Corresponding author:

Melanie Khamis

IZA

P.O. Box 7240

53072 Bonn

Germany

E-mail: khamis@iza.org

\footnotetext{
*I have benefited from the discussions with Ira Gang and Ravi Kanbur on the concept of informality. I thank Zahra Siddique for her comments. All errors are my own.
} 


\section{Introduction}

"Individuals are not informal; their actions and activities are. Nor do those who operate informally comprise a precise or static sector of society; they live within a gray area which has a long frontier with the legal world and in which individuals take refuge when the cost of obeying the law outweighs the benefit. Only rarely does informality mean breaking all the laws; most individuals disobey specific legal provisions [...].” Hernando de Soto. 1989. The Other Path. I.B. Tauris \& Co Ltd Publishers, London. p. 12

To address the question of 'informality' the existing literature has come up with various definitions and concepts. De Soto (1989) in his above quote emphasizes that there is no distinct border between formality and informality in the legal sense. Sometime one can find compliance to one regulation and non-compliance to another but as such there is no clear distinction between formality and informality according to a single concept. The "frontier" of informality and formality is extensive (De Soto 1989). In this respect it is necessary to determine what particular form of informality and what particular form of formality is present in the labor market under study (Fields 2009; Kanbur 2009). This has wider implications for labor market studies, which analyze the labor market and the nature of informality. The debate in the literature has centered around the question whether informal and formal labor markets are segmented or integrated. In the traditional view, based on the Harris-Todaro model, informal and formal labor markets are segmented. Informal workers are 'involuntary' in the informal labor market and barriers to entry prevent them to move in the formal labor market. Contrary to this, it has been argued that 'voluntary' choice of informal workers and self-employed also characterizes the informal labor market (Maloney 1999, 2004). Here, the two labor markets are not segmented but integrated. A third view proposed by Fields (1990) combines these two seemingly mutually exclusive views: the informal sector is seen as very heterogeneous and two-tier. Some informal sector participants are there involuntary and segmented from the formal labor market while others work voluntary in the informal sector.

To test the presence of segmentation, integration or a heterogeneous two-tier informal sector suggested by Fields (1990), empirical evidence generally tries to assess (1) the existence of a wage gap and/or (2) job mobility between the formal and informal 
segments. ${ }^{1}$ The majority of empirical evidence has so far been conducted in the developed country or Latin American context, partly due to data restrictions. However, some recent studies have looked at other developing countries in Africa and some transition economies.

Methodological differences in these empirical studies exist on several dimensions: definition of informality in the labor market, estimation strategies employed to address the econometric problems and the data sources to study these phenomena. The main differences among these studies are the following:

Definition of informality usually falls within the boundaries of the so-called productivity or legalistic definition in the labor market, depending on the data available. Data employed in the studies are usually national household survey data sets with individual observations. Cross-section and panel data, which are rarer in the developing country context, are exploited in the different studies. ${ }^{2}$ Estimation strategies of most of these studies have tried to address the econometric problems of selection on observables and unobservables, identification and endogeneity. ${ }^{3}$ The evidence corroborated by these studies so far gives a very mixed picture and lends credence to all three labor market paradigms (segmentation, integration and two-tier informal sector), depending on the country and time period under study. However, the definition of informality and the data available also provide a constraint in terms of analysis of the labor market and policy. The particular definition of informality and data availability make some of these studies and their conclusions about labor market segmentation or integration non-comparable and non-generalizable across countries or across time within one country. As Kanbur (2009)

\footnotetext{
${ }^{1}$ The existence of a wage gap between the formal and informal sector is usually taken as evidence of segmentation in the labor market. However, it has been argued that without an alternative model of an integrated or competitive labor market, this evidence could be misleading (Magnac 1991; Galiani and Weinschelbaum 2006). Job mobility, depending on the circumstances, could also be an indication of both segmentation and integration (e.g. job movement into the informal sector after an economic crisis could point at a segmented labor market while general job mobility could indicate no segmentation between the sectors).

${ }^{2}$ In some studies an explicit questions regarding the social security contribution or employment registration of the individual would allow a more precise coding of the legalistic definition (e.g. in the Brazilian case the question on whether the worker has a "card"/employment contract registration or not.). Recent surveys in Colombia and Bulgaria conducted by the World Bank included extensive questions on the social security system (Peracchi, Perotti and Scarpetta 2007; Perrotti 2008). Also supplementary questionnaires on informality, which were attached to national surveys, in Argentina, Bolivia, Colombia and Dominican Republic provide further information on social security and productivity measures of informality (World Bank 2007).

${ }^{3}$ The estimation strategies ranged from difference-in-difference estimation, propensity score matching, Heckman selection correction type estimation, treatment effects models, instrumental variable estimation, regression switching models, Markov processes to more descriptive methods and simpler regression models, depending on the data availability and question of interest of the study.
} 
argues the context of each particular study and the definition of informality, relative to a specific regulation, is also important for policy analysis. As he argues "policy analysis can also be affected, since very disparate situations are all given the same label, of 'informality', with a related tendency to apply the same policy instrument to very different situations” (Kanbur 2009, p.6).

Given the importance of understanding the nature of informality, this paper attempts to shed some light on the different concepts of informality and uses a data source to examine these empirically. This will give further insight for the applicability of certain policies to these contexts.

By no means is this paper an extensive review of the literature on all the different informality concepts in the literature. On the contrary, the attempt is made to understand a few distinct notions relating to informality, such as the productivity definition and the legalistic definition and to understand which regulation and degree of compliance to it is in place. In particular, I apply a novel data set on Mexico, which contains many questions relating to various dimensions of informality. This makes it possible to understand these concepts and their relationship to each other. Given the breadth of the dataset, it is possible to analyze various dimensions of informality relating to social security, contractual arrangements, migration, job history and different employment relationships such as self-employment in small firms. This has not been covered to this extent in the existing empirical literature on informality. ${ }^{4}$ The intention of this paper is to study the different informality measures, which are key starting points in empirical studies of labor market segmentation and integration as well as policy evaluation and design. ${ }^{5}$ Moreover, an attempt is made to understand the correlations of these different informality measures and also their determinants in terms of individual and household characteristics.

In the next section the main concepts on informality in the labor market are summarized and discussed. Then the Mexican data set is discussed and the various measures of informality estimated from this data set are introduced. Descriptive statistics for the various measures are discussed. The correlation between two legalistic measures, social security coverage and contractual arrangements, for 2005 and also for 2003 are then analyzed. Also the determinants, in terms of individual and household characteristics, of

\footnotetext{
4 The closest paper to this by Henley, Arabsheibani and Carneiro (2006) investigates informality in the Brazilian labor market. However, my paper looks at further dimensions of individual labor market informality such as migration and job history and thereby exploits the panel structure.

${ }^{5}$ As Fields (2009) argued, it is important to understand what measure of informality is in the studies at hand. He proposed instead of talking about "formality" versus "informality" that the actual dividing criteria should be used, such as “covered” versus “uncovered”.
} 
these particular forms of informality are estimated. Finally, this paper concludes with a discussion of the main results and their implications.

\section{Informality in the Labor Market}

The definition of informality and the informal sector poses a challenge in itself due to its very nature of not being easily observable (Schneider and Enste 2000; Mead and Morrisson 1996). A very broad definition defines the informal economy as including "unreported income from the production of legal goods and services, either from monetary or barter transactions, hence all economic activities that would generally be taxable were they reported to the tax authorities” (Schneider and Enste 2000, pp.78-79). ${ }^{6}$ As this paper is concerned about the functioning of formal and informal labor markets in developing and transition economies, my analysis restricts itself to the labor market and income generating activities as workers or the self-employed. ${ }^{7}$ Even with this restricted view informality in the labor market is difficult to pin down and can be characterized according to several dimensions, depending on data availability, the legal system present and nature of the labor market and occupations.

The productivity definition and legalistic definition of informality are the two most commonly employed in the labor market literature (World Bank 2007):

(1) The productivity definition characterizes informality in the labor market by job characteristics. The informal segment of the labor market under this definition constitutes non-professionals, unskilled, marginal jobs, the self-employed, domestic and family workers and workers in small firms with up to 5 employees (Hussmans 2004).

(2) The legalistic definition characterizes informality in the labor market by the noncompliance to the state in terms of labor laws and social security systems (Saavedra and Chong 1999). The informal segment of the labor market under this definition is characterized by workers and the self-employed non-compliant or without access to the social security system or pension system. ${ }^{8}$

\footnotetext{
${ }^{6}$ This definition excludes unpaid activities such as home production, which does not generate income, or illicit activities such as drug smuggling. A distinction between licit, illicit, legal and illegal is made in the economic sociology literature definition of informality (Portes and Haller 2005; Portes and Schauffler 1993).

${ }^{7}$ For a discussion of the evolution of the term of 'informality' and the different literatures see Kanbur (2009).

${ }^{8}$ In many countries waged workers and their employers are mandated to contribute to the social security system while for self-employed different rules and regulations exist and they often have to make their own pension arrangements and contributions.
} 
These two definitions of the informal labor market can, when looking at the data, overlap but still differ from each other and do not necessarily cover the same set of workers or self-employed in the informal sector (Gasparini and Tornarolli 2007; World Bank 2007). This indicates heterogeneity within the informal sector. In a recent study with Brazilian household data over the period 1992 to 2001, informality is analyzed using three different definitions of informality (employment contract registration, social security protection and the characteristics of the job) (Henley, Arabsheibani and Carneiro 2006). It is found that compositional changes and the likelihood of informality differ depending on the definition of informality. This is taking as growing heterogeneity of the informal sector over time (Henley, Arabsheibani and Carneiro 2006).

Given the ambiguity in these different concepts, the heterogeneity of the informal sector and the 'long frontier with the legal world' as De Soto (1989) put it, Kanbur (2009) argues the following:

“[...] every characterization of formality and informality needs to specify precisely the regulation concerned. Formality and informality are dichotomies relative only to specific interventions or regulations. This has two immediate implications.

First, definitions based on other criteria, such as size, or capital intensity, or degree of organization, or nature of competition, etc., cannot be used (unless, of course, the criterion itself appears in the regulation). Second, generic definitions of informality are not to be used, or at least are to be treated with careful scrutiny as regards their usefulness in analytical and policy discourse.” (Kanbur 2009, p.6-7). Kanbur (2009) goes a step further and links formality and informality relative to specific interventions, regulations and the degree of compliance. In his view various sets of regulations such as minimum wage laws, social security provision, health and safety regulations and others across various sectors can be distinguished according to agents and their behavior and activities after the intervention (Kanbur 2009). ${ }^{9}$

To distinguish formality and informality with respect to regulation and the various possibilities of compliance, non-compliance, adjustment and non-adjustment implies a dynamic view of informality in some sense, before and after regulation. From the empirical point of view this provides an additional challenge as one would need information not only at one point in time but also over time for an individual in a given

\footnotetext{
${ }^{9}$ He proposes four distinct possibilities, which then can distinguish formality and informality in some form (Kanbur 2009, p.7): “A. Stay within ambit of regulation and comply. B. Stay within the ambit of regulation but do not comply. C. Adjust activity to move out of ambit of regulation. D You are outside the ambit of regulation in the first place, so there is no need to adjust to it.”
} 
country. Also in the data set one would need to find information on various regulations and laws and the nature of compliance and non-compliance at various points in time and for the individual. Looking at these different measures will already provide an insight on the nature of informality with respect to a particular regulation, but it still leaves the question of enforcement open. The degree and intensity of enforcement, which according to Kanbur (2009) is crucial to understand the nature of informality, is most commonly not covered in the household level datasets and will not be easily uncovered.

In this paper it will only be possible to disentangle some of these regulations and interpret them and their compliance in the particular context of Mexico, and also for illegal migration in the context of the U.S..

In addition to that this paper also looks at the productivity measure of small-scale selfemployment.

\section{The case of Mexico: Data and Measures}

\subsection{Data $^{10}$}

This paper employs a unique dataset on Mexico to understand informality in the labor market and its various dimensions better. The Mexican Family Life Survey (MXFLS from now on) was collected in 2002 and 2005 with the purpose of providing detailed information on various aspects of Mexican life over time and space. The intention is to develop a longitudinal database which covers rural and urban locations across Mexico. The MXFLS-2 for 2005, which I work with in this paper, contains information for approximately 40 thousand individuals. Detailed questions for households and individuals, even migrants, cover standard topics such as education, employment, health, crime, expectations and preferences, household and individual characteristics. In addition detailed questions on various relevant aspects of the labor market are included. Questions relating benefits, social security, contracts, legal status of migrants, firm size and other information such as payments of wages and incomes and participation in government programs are elicited, which this paper employs to understand the nature of informality in Mexico.

\subsection{Mexican Measures of Informality}

The MXFLS data allows us to determine various dimensions of informality in the Mexican labor market. The productivity lens and more importantly the legalistic lens of

\footnotetext{
${ }^{10}$ The Mexican Family Life Survey (MXFLS) is publicly available under: www.ennvih-mxfls.org
} 
informality can be constructed with different measures. ${ }^{11}$ Details of the questions analyzed are provided in the Annex 1.

For the legalistic view of the labor market and the focus on which regulations apply this paper distinguishes several categories:

(1) Social Security and No Social Security for the current main job provided by the IMSS (the Instituto Mexicano del Seguro Social). This information is also available for 2003.

(2) Written contract and no written contract for the current main job. This information is also available for 2003.

(3) For the unemployed and the previous job history whether the person had social security or not and whether there was a written contract or not.

(4) Temporary or permanent migration to the U.S. without the legal documentation.

For the productivity view of the labor market this paper has employed the definitions often employed in the current literature on firm-size and self-employment and being a boss or employer.

(5) For the productivity related view this paper looks at the self-employed and bosses in small firms with a size of 1 to 5 workers.

\section{Results}

This section discusses the descriptive tables for the various dimensions of informality (social security coverage, contractual coverage, self-employment in small firms and illegal migration) and the correlation between two legalistic types of informality, social security and contractual arrangements, for the current job and the previous job history. Also probit models are estimated to understand the significance of different individual and household characteristics in the propensity to be formal or informal.

Table 1 compares the means for various characteristics for individuals, which report to have social security or not in their current main job. Looking at the means I find that the informal employees tend to be younger, female, unmarried, less educated and lower ability, which is measured by the score on the Raven's test. The informal workers also have a higher share of participation in government programs and a history of informality in terms of social security, which is indicated by not having social security in 2003. In

\footnotetext{
${ }^{11}$ Previous work on Mexico has included various dimensions, e.g. looking at social security coverage and health care coverage (Juarez 2009) or looking at the self-employed, formal and informal salaried (Bosch and Maloney 2007)
} 
terms of job history the currently unemployed, who answer questions on their last job, seems to have a similar shares of social security coverage or not.

Comparing individuals, who have a written contract or only a verbal/non-written contract, Table 2 exhibits some similar behavior in terms of means. Individuals without written contracts are younger, less educated, with lower Raven's test scores, lower income and have a history of previous informality in the contractual sense.

Moving onto the productivity measure of informality the means show that individuals tend to be older, married, on average have lower scores on the Raven's test, a job history of informality in terms of lack of social security and written contracts and have on average low incomes (with a large standard deviation tough) (Table 3).

Illegal migrants to the U.S., who do not possess the legal documentation, are more likely to be males, in their 20s and 30s, with low income and previous history of informality on the legal dimensions of informality (Table 3).

These results highlight the importance of the legal concept of informality of social security and contracts for workers, self-employed, illegal migrants and the unemployed.

There seems to be hysteresis in the Mexican labor market. Informality in the legal dimension persists over time. ${ }^{12}$

Correlating social security coverage and possession of a written contract for 2003 and 2005, Table 4 illustrates that there is a significant correlation between these dimensions of formality at a point in time and over time. The significance is even at the 1 percent level. To understand the propensity to be formal, or reversely informal, Table 5 to Table 7 present probit regressions and the marginal effects for the various informality measures. Gender, age, status in the household (household head), marital status, different education levels, region and industrial sector variables are included.

As the Mexican dataset MXFLS includes a cognitive ability measure, Raven's test, this paper uses the number of correct answers as an indication of ability and links it to informality and formality. De Mel et al. $(2008,2009)$ introduced these measures of ability in their studies of informality and self-employment. As can be seen from Figure 1, informal sector workers, workers without social security, and formal sector workers perform relatively similarly on this measure. Small differences at the lower and higher end of the distribution can be found for formal and informal workers. More informal

\footnotetext{
${ }^{12}$ Various reasons for the persistence of informality, no social security coverage, are named in the literature. Individuals could be myopic towards their future or from a cost-benefit calculation might not value social security (Levy 2008; World Bank 2007).
} 
workers have no or a few correct answers and a smaller percentage of informal workers have higher numbers of correct answers when compared to formal workers. The score on this test is also included in the probit regressions as variable, which may determine selection into a particular job and thereby formality or informality.

From Table 5 it is possible to see that older, married, higher educated individual have a higher propensity to be covered by social security. In addition to that also having a higher score in the Raven's test increases the probability to be formal. When looking at gender differences, it is notable that for females secondary education and a higher ability measure make it more likely to be formal while for males age, marriage, education and ability make it more likely to be formal.

For the other legalistic measure of informality, whether the individual has a written contract or not, age, secondary and tertiary education and the test score are significant and positive, for all and across gender (Table 6).

Contrary to this, I find for the self-employed and bosses in small firms, older individuals are more likely to participate in this sector while being single makes it less likely. Higher education levels make it also more likely while the ability measure remains insignificant (Table 7). For illegal migrants the results do not exhibit significance for the education or ability measure. Being female and a household head make it less likely to have an incidence of illegal migration to the United States.

\section{Conclusion}

As Guha-Khasnobis, Kanbur and Ostrom (2006) emphasize, the role and distinction between formality and informality is far from clarified and a set of working policies for the formal and informal labor market are not known with certainty either.

This note finds that the various legal measures of informality, whether the individual is covered by social security or has a written contract in the current job or in the previous job, are significantly correlated. An element of persistence of informality is present in the labor market. Moreover, age, martial status, education level and the score on the Raven's test, a measure of ability, are significant determinants whether the individual has social security or not or has a written contract or not.

For the self-employed in small firms age, education and being single are significant predictors of this category while the measure of ability is not. For illegal migrants, individuals who migrated temporary or permanently to the U.S. without legal documentation, being male and not a household head are significant determinants. 
The results of this paper demonstrate the need to investigate empirically the different forms of informality to inform the debate in the literature on whether the formal and informal labor market is segmented or integrated and the policy measures applicable to informality, which persists in the labor market over time.

Further extensions to this paper could include a detailed analysis of the different concepts of informality and job mobility and wages to test the degree of segmentation and integration of formal and informal labor markets and the persistence of informality. Overall, this paper intends to highlight the various dimensions of informality, in the particular country case of Mexico. Applications, implementations and data collection on various dimensions of regulations and measures of informality for other developing and transitions countries could shed further light on the rather complex phenomenon of informality in the labor market. This would provide further empirical data to analyze policies and their impact, which at present time is an emerging literature limited due to data availability on informality in the labor market and the wider economy. This would help us to gain insights on what policies are needed to tackle or work with particular forms of informality in a given country. 


\section{References}

Bosch, M. and W.F. Maloney. 2007. "Comparative Analysis of Labor Market Dynamics Using Markow Processes: An Application to Informality. " IZA DP. 3038.

De Mel, Suresh, David McKenzie, Christopher Woodruff. 2009. "Innovative Firms or Innovative Owners? Determinants of Innovation in Micro, Small and Medium Enterprises." IZA DP 3962.

De Mel, Suresh, David McKenzie, Christopher Woodruff. 2008. " Who Are the Microenterprise Owners? Evidence from Sri Lanka and Tokman v. de Soto." IZA DP 3511.

De Soto, Hernando. 1989. The Other Path - The invisible revolution in the third world, I.B. Tauris \& Co Ltd Publishers, London.

Fields, Gary S..1990."Labour market modelling and the urban informal sector: theory and evidence." in The Informal Sector Revisited. David Turnham, Bernard Salomé and Antoine Schwarz ed: OECD. Paris.

Fields, Gary S. 2009. Keynote Lecture $4^{\text {th }}$ IZA/World Bank Employment and Development Conference. Bonn. May 4-6, 2009.

Galiani, Sebastian and Federico Weinschelbaum. 2006. "Modeling Informality Formally: Households and Firms." Mimeo.

Gasparini, Leonardo and Leopoldo Tornarolli. 2007. "Labor Informality in Latin America and the Caribbean: Patterns and Trends from Household Survey Microdata.” CEDLAS Working Paper February 2007.

Guha-Khasnobis, Basudeb, Ravi Kanbur and Elinor Ostrom (eds.). 2006. Linking the Formal and Informal Economy: Concepts and Policies. Oxford University Press. Oxford.

Juarez, Laura. 2009."Are Informal Workers Compensated for the Lack of Fringe Benefits? Free Health Care as an Instrument for Formality." Working Paper presented at IZA/SOLE Meeting May 2009.

Harris, John R. and Michael P. Todaro. 1970. "Migration, Unemployment, and Development: A Two-Sector Analysis.” The American Economic Review, 60(1): 126142.

Henley, Andrew, G. Reza Arabsheibani and Francisco G. Carneiro. 2006. “On Defining and Measuring the Informal Sector.” IZA Discussion Paper No. 2473.

Hussmanns, Ralf. 2004. "Defining and measuring informal employment." International Labour Office working paper: Geneva.

Lemos, S.. 2009. "Minimum wage effects in a developing country," Labour Economics. Elsevier, vol. 16(2), p. 224-237, April. 
Levy, Santiago. 2008. Good Intentions, Bad Outcomes: Social Policy, Informality and Economic Growth in Mexico. Washington DC: Brookings Institution Press.

Kanbur, Ravi. 2009. "Conceptualizing Informality: Regulation and Enforcement." February, 2009 V.V. Giri Memorial Lecture. Forthcoming in Indian Journal of Labour Economics. IZA Discussion Paper No. 4186.

Khamis, Melanie. 2008. "Does the Minimum Wage Have a Higher Impact on the Informal than on the Formal Labor Market? Evidence from Quasi-Experiments." IZA DP 3911.

Magnac, Th.. 1991. "Segmented or Competitive Labor Markets." Econometrica, 59, pp.165-187.

Maloney, William F..1999."Does Informality Imply Segmentation in Urban Labor Markets? Evidence from Sectoral Transitions in Mexico." World Bank Economic Review, 13, pp.275-302.

Maloney, William F.. 2004. “Informality Revisited.” World Development, 32(7): 1159 1178.

Mead, Donald C. and Christian Morrisson. 1996. “The informal sector elephant.” World Development, 24(10): 1611-1619.

Peracchi, F., V. Perotti and S.Scarpetta. 2007. "Informality and Social Protection: Preliminary Results from Pilot Surveys in Bulgaria and Colombia. " The World Bank. Social Protection Discussion Paper 0717.

Perotti, V. 2008. Social security choices and expected survival. Doctoral Dissertation. Universita` degli Studi di Roma “Tor Vergata”.

Portes, Alejandro and William Haller. 2005 “The Informal Economy.” In The Handbook of Economic Sociology, N. Smelser and R. Swedberg (eds.) 2nd edition, New York: Russell Sage Foundation.

Portes, Alejandro and Richard Schauffler. 1993. "Competing Perspectives on the Latin American Informal Sector.” Population and Development Review, 19(1):33-60.

Rubalcava, Luis and Graciela. Teruel. 2007. "User’s Guide: Mexican Family Life Survey 2005.” Website last accessed 29 $9^{\text {th }}$ November 2009) http://www.ennvihmxfls.org/en/mxfls.php?subseccion=ver\&session=79462117164\#.

Saavedra, Jaime and Alberto Chong. 1999. "Structural Reform, Institutions and Earnings: Evidence from the Formal and Informal Sectors in Urban Peru." Journal of Development Studies, 35, pp.95-116.

Schneider , Friedrich and Dominik H Enste. 2000. "Shadow Economies: Size, Causes and Consequences. " Journal of Economic Literature, 38(March):77-114. 
World Bank. 2007. Informality: Exit and Exclusion. Latin American and Caribbean Region. Washington DC. 


\section{Annex 1: Questions in MXFLS-2}

These questions are extracted from the survey documentation of the MXFLS-2, which are available under www.ennvih-mxfls.org.

\section{(1) Main job and dimensions of legality and informality:}

A question posed to individuals about the current main and secondary job allows covers the contractual situation, the legal status in terms of social security coverage, contractual relationship, health insurance and bonus payments:

When you work as [...], do you have (...)? (Circle All That Apply)

1. Written contract for an indefinite amount of time (basis, settled, trusting position, etc.)

2. Written contract for determined time or for a specific job

3. Verbal contract (does not have a written contract)

4. Social Security (IMSS)

5. ISSSTE, PEMEX, SEDENA or SECMAR

6. Private medical insurance given by the company/business

7. AFORE or SAR (savings system for retirement)

8. Christmas bonus

9. None of the above

\section{(2) Job history and dimensions of legality and informality:}

The above question was also asked to the unemployed about their previous jobs and also about job history information relating to job status in the year 2003.

\section{(3) Migration and dimensions of legality and informality:}

Permanent migrants, migrants who stayed one year or longer, are asked the following question:

At the time you moved to [...] did you have any legal documentation that allowed you entry into the USA?

1. Visa

2. Green card

3. American citizenship

4. Did not have legal documents

5. Other (specify)

For temporary migrants, who stayed one to twelve months, an analogous question is posited: 
At the time of your trip to [...] did you have any legal documentation that allowed you entry to the USA?

1. Visa

2. Green card

3. American citizenship

4. Did not have legal documents

5. Other (specify)

\section{(4) Informality and non-labor income from government programs}

To determine the link between informality in the labor market, measured on various dimensions, and the receipt of non-labor income from government programs, also questions relating to various programs will be employed.

The following questions asked about the different programs, Oportunidades (before Progresa), Procampo, Vivah, work credit program, social coinvestment, Pet program and Alianza por el campo are analyzed: ${ }^{13}$

Name of the program directly paid to you

1. You are a participant, and you have received income

2. You are a participant, but you have not received income

3. Not a participant

(5) Employment and dimensions of productivity unit and informality:

Self-employment and comisionistas, who according to Levy (2008) are "working on their own or in a legal nonsalaried capacity with a firm” can also be determined in the dataset. In this paper I focused on the self-employed and employers/bosses in small firms (1-5).

The self-employed in small firms can be found through the following two questions in the main job:

(1) Then, when you work as [...], are you (...)?

1. Farmer on your own plot.

2. Family worker in a household owned business, without wages

3. Non-agricultural worker or employee

4. Rural laborer, or land farmhand (agricultural worker)

5. Boss, employer or business proprietor

6. Self-employed worker (with or without monetary compensation)

${ }^{13}$ The question on Oportunidades was asked according to the questionnaire but it seems the data are not available in the dataset at present. 
7. Worker without monetary compensation from a business or company that is not owned by the household

(2) How many people, including yourself, worked during the past month at your work place (office, company, shop, business etc.)

1. Number of people

\section{(6) Earnings}

To determine the earnings and the nature of earnings:

How much did you earn last month, since (SAY THE PREVIOUS MONTH'S DATE) until today, for working as [...]? Amounts in Dollar
A. Wage or salary (after taxes)
B. Payment per pieceworks
C. Commissions and tips
D. Extra hours
E. Meals
F. Housing
G. Transportation
H. Medical Benefits
I. Others (specify) 


\section{Tables and Figures}

Table 1: Dimensions of Informality: Social Security

\begin{tabular}{|c|c|c|c|c|}
\hline \multicolumn{5}{|c|}{ Dimensions of Informality: Social Security } \\
\hline & \multirow{2}{*}{$\frac{\text { Social Security }}{\text { Mean }}$} & \multicolumn{3}{|c|}{ No Social Security } \\
\hline & & $\mathrm{N}$ & Mean & $\mathrm{N}$ \\
\hline \multicolumn{5}{|l|}{ Age } \\
\hline below 15 & 0.23 & 4 & 1.5 & 60 \\
\hline 15 to 25 & 26.85 & 476 & 29.61 & 1,184 \\
\hline 25 to 35 & 31.47 & 558 & 25.54 & 1,021 \\
\hline 35 to 45 & 22.90 & 406 & 22.31 & 892 \\
\hline 45 to 55 & 13.48 & 239 & 13.61 & 544 \\
\hline 55 to 65 & 3.78 & 67 & 5.7 & 228 \\
\hline above 65 & 1.30 & 23 & 1.73 & 69 \\
\hline \multicolumn{5}{|l|}{ Gender } \\
\hline Female & 35.25 & 632 & 38.24 & 1,546 \\
\hline Male & 64.75 & 1,161 & 61.76 & 2,497 \\
\hline \multicolumn{5}{|l|}{ Education } \\
\hline No education & 1.62 & 29 & 4.03 & 163 \\
\hline Primary education & 23.76 & 426 & 29.46 & 1,191 \\
\hline Secondary education & 57.11 & 1,024 & 50.53 & 2,043 \\
\hline Tertiary education & 16.06 & 288 & 14.1 & 570 \\
\hline \multicolumn{5}{|l|}{ Family Status } \\
\hline Married & 51.87 & 930 & 45.58 & 1,843 \\
\hline Cohabiting & 8.70 & 156 & 10.83 & 438 \\
\hline Single & 30.90 & 554 & 34.88 & 1,410 \\
\hline Divorced/Separated/Widowed & 8.09 & 145 & 8.24 & 333 \\
\hline Household head & 46.46 & 833 & 41.9 & 1,694 \\
\hline \multicolumn{5}{|l|}{ A bility Measure } \\
\hline \multirow[t]{2}{*}{ Number of correct answers } & 7.238 & 1215 & 6.928 & 2818 \\
\hline & [2.702] & & {$[2.722]$} & \\
\hline Income 1/ & 4959.5 & 1522 & 4193.1 & 3433 \\
\hline & [5452.1] & & [5128.5] & \\
\hline \multicolumn{5}{|l|}{ Non-labor income 21} \\
\hline Program participants & 1.28 & 23 & 2.25 & 91 \\
\hline \multicolumn{5}{|l|}{ History of Informality 3 I } \\
\hline No social security & 13.51 & 178 & 94.1 & 2,454 \\
\hline No contract & 12.38 & 137 & 38.7 & 661 \\
\hline Currently Unem ployed 4/ & 9.6 & 41 & 9.62 & 100 \\
\hline Total Observations & 1,793 & & 4,043 & \\
\hline
\end{tabular}

Source: Author's calculations based on MXFLS- 2 .

Notes:

Numbers in Percent and standard deviations in bracktets unless otherwise reported.

Percent refers to each sample (column) as its own reference group.

Social Security in main job. No social security in main job. For employees.

1 / In Dollars, monthly income main job, average.

2/ Oportunidades variable is not available in MXFLS-2 dataset at present. Participants in other programs are included. 3/ In 2003.

4/ For the currently unemployed whether in the last job they had social security or not. 
Table 2: Dimensions of Informality: Contracts

\begin{tabular}{|c|c|c|c|c|}
\hline \multicolumn{5}{|c|}{ Dimensions of Informality: Contracts } \\
\hline & \multirow{2}{*}{$\begin{array}{c}\text { Contract } \\
\text { Mean }\end{array}$} & \multicolumn{3}{|c|}{ No contract } \\
\hline & & $\mathrm{N}$ & Mean & $\mathrm{N}$ \\
\hline \multicolumn{5}{|l|}{ Age } \\
\hline below 15 & 0.36 & 10 & 2.01 & 26 \\
\hline 15 to 25 & 24.28 & 674 & 34.72 & 450 \\
\hline 25 to 35 & 30.22 & 839 & 24.23 & 314 \\
\hline 35 to 45 & 25.36 & 704 & 19.68 & 255 \\
\hline 45 to 55 & 14.23 & 395 & 11.88 & 154 \\
\hline 55 to 65 & 4.43 & 123 & 5.4 & 70 \\
\hline above 65 & 1.12 & 31 & 2.08 & 27 \\
\hline \multicolumn{5}{|l|}{ Gender } \\
\hline Female & 38.54 & 1,083 & 36.8 & 481 \\
\hline Male & 61.46 & 1,727 & 63.2 & 826 \\
\hline \multicolumn{5}{|l|}{ Education } \\
\hline No education & 1.35 & 38 & 4.59 & 60 \\
\hline Primary education & 17.94 & 504 & 34.2 & 447 \\
\hline Secondary education & 56.12 & 1,577 & 51.03 & 667 \\
\hline Tertiary education & 22.56 & 634 & 8.57 & 112 \\
\hline \multicolumn{5}{|l|}{ Family Status } \\
\hline Married & 52.03 & 1,462 & 39.94 & 522 \\
\hline Cohabiting & 8.9 & 250 & 12.39 & 162 \\
\hline Single & 31.03 & 872 & 39.48 & 516 \\
\hline Divorced/Separated/Widowed & 7.51 & 211 & 7.96 & 104 \\
\hline Household head & 44.88 & 1,261 & 40.78 & 533 \\
\hline \multicolumn{5}{|l|}{ A bility Measure } \\
\hline \multirow[t]{2}{*}{ Number of correct answers } & 7.434 & 1878 & 6.684 & 935 \\
\hline & [2.671] & & [2.735] & \\
\hline Income $1 /$ & $\begin{array}{c}5644.4 \\
{[6358.2]}\end{array}$ & 2372 & $\begin{array}{c}3326.4 \\
{[3584.3]}\end{array}$ & 1120 \\
\hline \multicolumn{5}{|l|}{ Non-labor income 21} \\
\hline Program participants & 1.32 & 37 & 2.52 & 33 \\
\hline \multicolumn{5}{|l|}{ History of Informality 3} \\
\hline No social security & 54.12 & 1,111 & 82.02 & 689 \\
\hline No contract & 4.62 & 90 & 87.83 & 671 \\
\hline Currently Unemployed 4/ & 9.17 & 52 & 8.61 & 39 \\
\hline Total Observations & 2,810 & & 1,307 & \\
\hline \multicolumn{5}{|c|}{$\begin{array}{l}\text { Source: Author's calculations based on MXFLS- } 2 \text {. } \\
\text { Notes: }\end{array}$} \\
\hline \multicolumn{5}{|c|}{ Numbers in Percent and standard deviations in bracktets unless otherwise reported. } \\
\hline \multicolumn{5}{|c|}{ Percent refers to each sample (column) as its own reference group. } \\
\hline \multicolumn{5}{|c|}{ Contract: written for main job, No contract: only verbal contract for main job. For employees. } \\
\hline \multicolumn{5}{|c|}{ 1/ In Dollars, monthly income main job, average. } \\
\hline \multirow{2}{*}{\multicolumn{5}{|c|}{$\begin{array}{l}\text { 2/ Oportunidades variable is not available in MXFLS- } 2 \text { dat aset at present. } \\
\text { Participants in other programs are included. }\end{array}$}} \\
\hline & & & & \\
\hline 3/ In 2003. & & & & \\
\hline
\end{tabular}


Table 3: Dimensions of Informality: Self-employment and Migration

\begin{tabular}{|c|c|c|c|c|}
\hline \multicolumn{5}{|c|}{ Dimensions of Informality: Self-employment and Migration } \\
\hline & \multicolumn{2}{|c|}{ Self-employed } & \multicolumn{2}{|l|}{ Illegal migrants } \\
\hline & Mean & $\mathrm{N}$ & Mean & $\mathrm{N}$ \\
\hline \multicolumn{5}{|l|}{ Age } \\
\hline below 15 & 0.27 & 5 & 0.99 & 1 \\
\hline 15 to 25 & 11.11 & 202 & 25.74 & 26 \\
\hline 25 to 35 & 18.64 & 339 & 38.61 & 39 \\
\hline 35 to 45 & 26.17 & 476 & 20.79 & 21 \\
\hline 45 to 55 & 22.26 & 405 & 7.92 & 8 \\
\hline 55 to 65 & 13.25 & 241 & 3.96 & 4 \\
\hline above 65 & 8.3 & 151 & 1.98 & 2 \\
\hline \multicolumn{5}{|l|}{ Gender } \\
\hline Female & 44.53 & 814 & 19.42 & 20 \\
\hline Male & 55.47 & 1,014 & 80.58 & 83 \\
\hline \multicolumn{5}{|l|}{ Education } \\
\hline No education & 9.96 & 182 & 4.85 & 5 \\
\hline Primary education & 45.19 & 826 & 38.83 & 40 \\
\hline Secondary education & 34.52 & 631 & 47.57 & 49 \\
\hline Tertiary education & 9.35 & 171 & 2.91 & 3 \\
\hline \multicolumn{5}{|l|}{ Family Status } \\
\hline Married & 60.94 & 1,114 & 55.34 & 57 \\
\hline Cohabiting & 10.89 & 199 & 11.65 & 12 \\
\hline Single & 16.25 & 297 & 28.16 & 29 \\
\hline Divorced/Separated/Widowed & 11.87 & 217 & 4.85 & 5 \\
\hline Household head & 53.23 & 973 & 38.83 & 40 \\
\hline \multicolumn{5}{|l|}{ A bility Measure } \\
\hline \multirow[t]{2}{*}{ Number of correct answers } & 6.492 & 932 & 6.819 & 83 \\
\hline & [2.836] & & [2.572] & \\
\hline \multirow[t]{2}{*}{ Income 1/ } & 2285.9 & 1536 & 3846.1 & 39 \\
\hline & [10378.5] & & [3242.8] & \\
\hline \multicolumn{5}{|l|}{ Non-labor income $2 I$} \\
\hline Program participants & 2.35 & 43 & 5.83 & 6 \\
\hline \multicolumn{5}{|l|}{ History of Informality 3 I } \\
\hline No social security & 72.57 & 82 & 84.78 & 39 \\
\hline No contract & 42.47 & 31 & 48.15 & 13 \\
\hline$\overline{\text { Total Observations }}$ & 1,828 & & 103 & \\
\hline \multicolumn{5}{|c|}{ Source: Author's calculations based on MXFLS- 2 . } \\
\hline \multicolumn{5}{|l|}{ Notes: } \\
\hline \multicolumn{5}{|c|}{ Numbers in Percent and standard deviations in bracktets unless otherwise reported. } \\
\hline \multicolumn{5}{|c|}{ Percent refers to each sample (column) as its own reference group. } \\
\hline \multicolumn{5}{|c|}{ Self-employed/employers in small fims (1-5 employees) } \\
\hline \multicolumn{5}{|c|}{ and migrants to the U.S. without legal documentation. } \\
\hline \multicolumn{5}{|c|}{ 1/ In Dollars, monthly net income/profits, average. } \\
\hline \multicolumn{5}{|c|}{ 2/ Oportunidades variable is not available in MXFLS-2 dataset at present. } \\
\hline Participants in other programs are incle & ded. & & & \\
\hline $3 / \ln 2003$ & & & & \\
\hline
\end{tabular}


Table 4: Correlation Coefficients between different dimensions of formality in 2003 and 2005

\begin{tabular}{|c|c|c|c|c|}
\hline \multicolumn{5}{|c|}{ Correlation Coefficients between different dimensions of formality in 2003 and 2005} \\
\hline & social security 2005 & contract 2005 & social security 2003 & contract 2003 \\
\hline social security 2005 & 1 & $\ldots$ & $\ldots$ & $\ldots$ \\
\hline contract 2005 & $0.3600 *$ & 1 & $\ldots$ & $\ldots$ \\
\hline social security 2003 & $0.8096^{*}$ & $0.2613^{*}$ & 1 & $\ldots$ \\
\hline contract 2003 & $0.2853^{*}$ & $0.8331^{*}$ & $0.3557^{*}$ & 1 \\
\hline
\end{tabular}

Source: Author's calculations based on MXFLS-2.

Asterisks denotes significance at 1 percent level

Employees only.

Table 5: Determinants of Informality (Legalistic measure, social security): Probit Models

\begin{tabular}{|c|c|c|c|c|c|c|}
\hline \multicolumn{7}{|c|}{ Determinants of Informality (Legalistic measure, social security): Probit Models } \\
\hline & All & & Female & & Male & \\
\hline & (1) & (2) & (1) & (2) & (1) & (2) \\
\hline female & $\begin{array}{c}-0.039 \\
{[0.060]}\end{array}$ & $\begin{array}{c}-0.013 \\
{[0.020]}\end{array}$ & $\begin{array}{l}\ldots \\
\ldots\end{array}$ & $\begin{array}{l}\ldots \\
\ldots\end{array}$ & $\cdots$ & $\ldots$ \\
\hline age & $0.006^{\star *}$ & $0.002^{\star *}$ & 0.004 & 0.001 & $0.008^{\star *}$ & $0.003^{\star *}$ \\
\hline & [0.003] & [0.001] & [0.005] & [0.002] & [0.004] & [0.001] \\
\hline household head & $\begin{array}{c}0.043 \\
{[0.071]}\end{array}$ & $\begin{array}{c}0.014 \\
{[0.023]}\end{array}$ & $\begin{array}{l}-0.038 \\
{[0.145]}\end{array}$ & $\begin{array}{c}-0.012 \\
{[0.045]}\end{array}$ & $\begin{array}{c}0.088 \\
{[0.099]}\end{array}$ & $\begin{array}{c}0.029 \\
{[0.033]}\end{array}$ \\
\hline married & $\begin{array}{l}0.197^{\star \star} \\
{[0.095]}\end{array}$ & $\begin{array}{l}0.065^{\star \star} \\
{[0.032]}\end{array}$ & $\begin{array}{c}0.086 \\
{[0.174]}\end{array}$ & $\begin{array}{c}0.028 \\
{[0.057]}\end{array}$ & $\begin{array}{l}0.191^{*} \\
{[0.116]}\end{array}$ & $\begin{array}{c}0.063^{\star} \\
{[0.038]}\end{array}$ \\
\hline single & $\begin{array}{c}0.129 \\
{[0.098]}\end{array}$ & $\begin{array}{c}0.042 \\
{[0.032]}\end{array}$ & $\begin{array}{l}-0.032 \\
{[0.172]}\end{array}$ & $\begin{array}{c}-0.01 \\
{[0.055]}\end{array}$ & $\begin{array}{c}0.201 \\
{[0.126]}\end{array}$ & $\begin{array}{c}0.067 \\
{[0.043]}\end{array}$ \\
\hline divorced/separated & $\begin{array}{c}0.16 \\
{[0.131]}\end{array}$ & $\begin{array}{c}0.054 \\
{[0.046]}\end{array}$ & $\begin{array}{c}0.148 \\
{[0.198]}\end{array}$ & $\begin{array}{c}0.049 \\
{[0.067]}\end{array}$ & $\begin{array}{c}0.09 \\
{[0.220]}\end{array}$ & $\begin{array}{c}0.03 \\
{[0.076]}\end{array}$ \\
\hline primary edu. & $\begin{array}{l}0.359^{\star \star} \\
{[0.158]}\end{array}$ & $\begin{array}{l}0.123^{\star *} \\
{[0.056]}\end{array}$ & $\begin{array}{c}0.143 \\
{[0.249]}\end{array}$ & $\begin{array}{c}0.047 \\
{[0.083]}\end{array}$ & $\begin{array}{l}0.478^{\star \star} \\
{[0.211]}\end{array}$ & $\begin{array}{l}0.165^{\star \star} \\
{[0.076]}\end{array}$ \\
\hline secondary edu. & $\begin{array}{c}0.629 * \star \star \\
{[0.156]}\end{array}$ & $\begin{array}{c}0.200 * \star \star \\
{[0.048]}\end{array}$ & $\begin{array}{l}0.499 * * \\
{[0.241]}\end{array}$ & $\begin{array}{l}0.155^{\star *} \\
{[0.073]}\end{array}$ & $\begin{array}{c}0.654^{\star \star *} \\
{[0.209]}\end{array}$ & $\begin{array}{c}0.210^{\star * \star} \\
{[0.065]}\end{array}$ \\
\hline tertiary edu. & $\begin{array}{c}0.591 * \star * \\
{[0.164]}\end{array}$ & $\begin{array}{c}0.212^{\star \star *} \\
{[0.063]}\end{array}$ & $\begin{array}{c}0.372 \\
{[0.254]}\end{array}$ & $\begin{array}{c}0.127 \\
{[0.091]}\end{array}$ & $\begin{array}{c}0.652 * \star * \\
{[0.220]}\end{array}$ & $\begin{array}{c}0.238^{\star \star *} \\
{[0.085]}\end{array}$ \\
\hline score in Raven's test & $\begin{array}{c}0.019^{*} \\
{[0.010]}\end{array}$ & $\begin{array}{l}0.006^{\star} \\
{[0.003]}\end{array}$ & $\begin{array}{c}0.047^{\star \star \star} \\
{[0.016]}\end{array}$ & $\begin{array}{c}0.015^{\star \star \star} \\
{[0.005]}\end{array}$ & $\begin{array}{c}-0.002 \\
{[0.013]}\end{array}$ & $\begin{array}{l}-0.001 \\
{[0.004]}\end{array}$ \\
\hline Observations & 2934 & 2934 & 1154 & 1154 & 1780 & 1780 \\
\hline
\end{tabular}

Source: Author's calculations based on MXFLS-2.

Notes:

Dependent variable: 1 for formal and 0 for informal, employees, social security or not.

Mean of dependent variable 0.31 .

(1) Probit regression, (2) marginal effects.

State and Industrial sector controls included. Base Mexico City and Manufacturing.

No education and with unmarried partner, omitted categories.

edu.: education

score in Raven's test: measure for ability 
Table 6: Determinants of Informality (Legalistic measure, contract): Probit Models

\begin{tabular}{|c|c|c|c|c|c|c|}
\hline \multicolumn{7}{|c|}{ Determinants of Informality (Legalistic measure, contract): Probit Models } \\
\hline & All & & Female & & Male & \\
\hline & (1) & (2) & (1) & (2) & (1) & (2) \\
\hline \multirow[t]{2}{*}{ female } & -0.034 & -0.012 & $\ldots$ & $\ldots$ & , & $\ldots$ \\
\hline & [0.071] & [0.026] & $\ldots$ & & & \\
\hline \multirow[t]{2}{*}{ age } & $0.017^{\star \star *}$ & $0.006^{\star \star *}$ & $0.021^{\star * \star}$ & $0.008^{\star * *}$ & $0.016^{\star \star \star}$ & $0.006^{\star \star \star}$ \\
\hline & [0.003] & [0.001] & {$[0.006]$} & [0.002] & [0.005] & {$[0.002]$} \\
\hline \multirow[t]{2}{*}{ household head } & 0.004 & 0.001 & -0.106 & -0.039 & 0.046 & 0.017 \\
\hline & [0.086] & [0.031] & [0.171] & [0.063] & [0.119] & [0.044] \\
\hline \multirow[t]{2}{*}{ married } & $0.227^{\star \star}$ & $0.082^{\star \star}$ & 0.287 & 0.099 & 0.176 & 0.065 \\
\hline & [0.110] & [0.039] & [0.204] & [0.068] & [0.132] & [0.049] \\
\hline \multirow[t]{2}{*}{ single } & -0.075 & -0.027 & -0.015 & -0.005 & -0.081 & -0.03 \\
\hline & [0.111] & [0.041] & [0.198] & [0.071] & [0.142] & [0.053] \\
\hline \multirow[t]{2}{*}{ divorced/separated } & 0.024 & 0.009 & 0.253 & 0.086 & -0.32 & -0.124 \\
\hline & [0.152] & [0.055] & [0.231] & [0.074] & [0.259] & [0.103] \\
\hline \multirow[t]{2}{*}{ primary edu. } & 0.23 & 0.082 & 0.052 & 0.018 & 0.343 & $0.122^{*}$ \\
\hline & [0.166] & [0.057] & {$[0.275]$} & [0.097] & [0.212] & [0.072] \\
\hline \multirow[t]{2}{*}{ secondary edu. } & $0.805^{\star \star \star}$ & $0.294^{\star \star *}$ & $0.806^{\star \star \star}$ & $0.290^{\star \star \star}$ & $0.797^{\star \star \star}$ & $0.292^{\star \star \star}$ \\
\hline & [0.161] & [0.057] & [0.265] & [0.093] & [0.208] & {$[0.074]$} \\
\hline tertiary edu. & $1.100 * \star \star$ & $0.324^{\star \star *}$ & $1.216^{\star \star *}$ & $0.343^{\star * *}$ & $0.999 * \star *$ & $0.303^{\star \star \star}$ \\
\hline \multirow[t]{2}{*}{ score in Raven's test } & $0.051^{\star \star \star}$ & $0.019 * \star \star$ & $0.060^{\star \star \star}$ & $0.021^{* * *}$ & $0.040 * \star \star$ & $0.015^{\star \star \star}$ \\
\hline & [0.012] & [0.004] & {$[0.019]$} & {$[0.007]$} & {$[0.015]$} & {$[0.005]$} \\
\hline Observations & 2037 & 2037 & 818 & 818 & 1219 & 1219 \\
\hline
\end{tabular}

Source: Author's calculations based on MXFLS-2.

Notes:

Dependent variable: 1 for formal and 0 for informal, employees, written contract or not. Mean of dependent variable 0.68 .

(1) Probit regression, (2) marginal effects.

State and Industrial sector controls included. Base Mexico City and Manufacturing.

No education and with unmarried partner, omitted categories.

edu.: education

score in Raven's test: measure for ability 
Table 7: Determinants of Informality (productivity measure and migration): Probit Models

\begin{tabular}{|c|c|c|c|c|}
\hline \multicolumn{5}{|c|}{ Determinants of Informality (productivity measure and migration): Probit Models } \\
\hline & \multicolumn{2}{|c|}{ Productivity Measure } & \multicolumn{2}{|c|}{ Migration } \\
\hline & (1) & (2) & (1) & (2) \\
\hline \multirow[t]{2}{*}{ female } & 0.04 & 0.012 & $-1.013^{\star \star \star}$ & 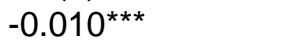 \\
\hline & [0.069] & [0.021] & [0.249] & [0.002] \\
\hline \multirow[t]{2}{*}{ age } & $0.018^{\star \star \star *}$ & $0.005^{\star * \star}$ & 0.001 & 0 \\
\hline & {$[0.003]$} & [0.001] & {$[0.006]$} & {$[0.000]$} \\
\hline \multirow[t]{2}{*}{ household head } & -0.068 & -0.021 & $-0.611^{\star \star \star}$ & $-0.007^{\star \star \star}$ \\
\hline & [0.074] & [0.023] & [0.160] & [0.002] \\
\hline \multirow[t]{2}{*}{ married } & 0.12 & 0.037 & 0.269 & 0.003 \\
\hline & [0.090] & {$[0.028]$} & [0.212] & [0.003] \\
\hline \multirow[t]{2}{*}{ single } & $-0.245^{\star *}$ & $-0.073^{\star *}$ & -0.28 & -0.003 \\
\hline & {$[0.098]$} & [0.029] & {$[0.228]$} & {$[0.003]$} \\
\hline \multirow[t]{2}{*}{ divorced/separated } & -0.031 & -0.009 & -0.169 & -0.002 \\
\hline & [0.130] & [0.039] & [0.442] & [0.004] \\
\hline \multirow[t]{2}{*}{ primary edu. } & $0.226^{\star \star}$ & $0.070^{\star \star}$ & 0.06 & 0.001 \\
\hline & [0.110] & [0.035] & [0.243] & [0.003] \\
\hline \multirow[t]{2}{*}{ secondary edu. } & $0.425^{\star \star \star}$ & $0.132^{\star \star \star}$ & -0.11 & -0.001 \\
\hline & {$[0.117]$} & {$[0.036]$} & [0.256] & [0.003] \\
\hline \multirow[t]{2}{*}{ tertiary edu. } & $0.556^{\star \star \star}$ & $0.194^{\star * *}$ & -0.322 & -0.003 \\
\hline & [0.138] & [0.052] & [0.344] & [0.002] \\
\hline \multirow[t]{2}{*}{ score in Raven's test } & -0.003 & -0.001 & -0.002 & 0 \\
\hline & [0.010] & [0.003] & [0.023] & [0.000] \\
\hline Observations & 2858 & 2858 & 5005 & 5005 \\
\hline
\end{tabular}

Source: Author's calculations based on MXFLS-2.

Notes:

Dependent variable (productivity measure):

1 Self-employed/bosses in small firms 0 for other employed in small firms.

Mean of dependent variable: For productivity measure 0.31

Dependent variable (migration): 1 illegal migrant (temporary or permanent) 0 other employed.

Mean of dependent variable: For migration 0.01

(1) Probit regression, (2) marginal effects.

State and Industrial sector controls included. Base Mexico City and Manufacturing.

No education and with unmarried partner, omitted categories.

edu.: education

score in Raven's test: measure for ability 
Figure 1: Ability and Informality (Legalistic Measure)

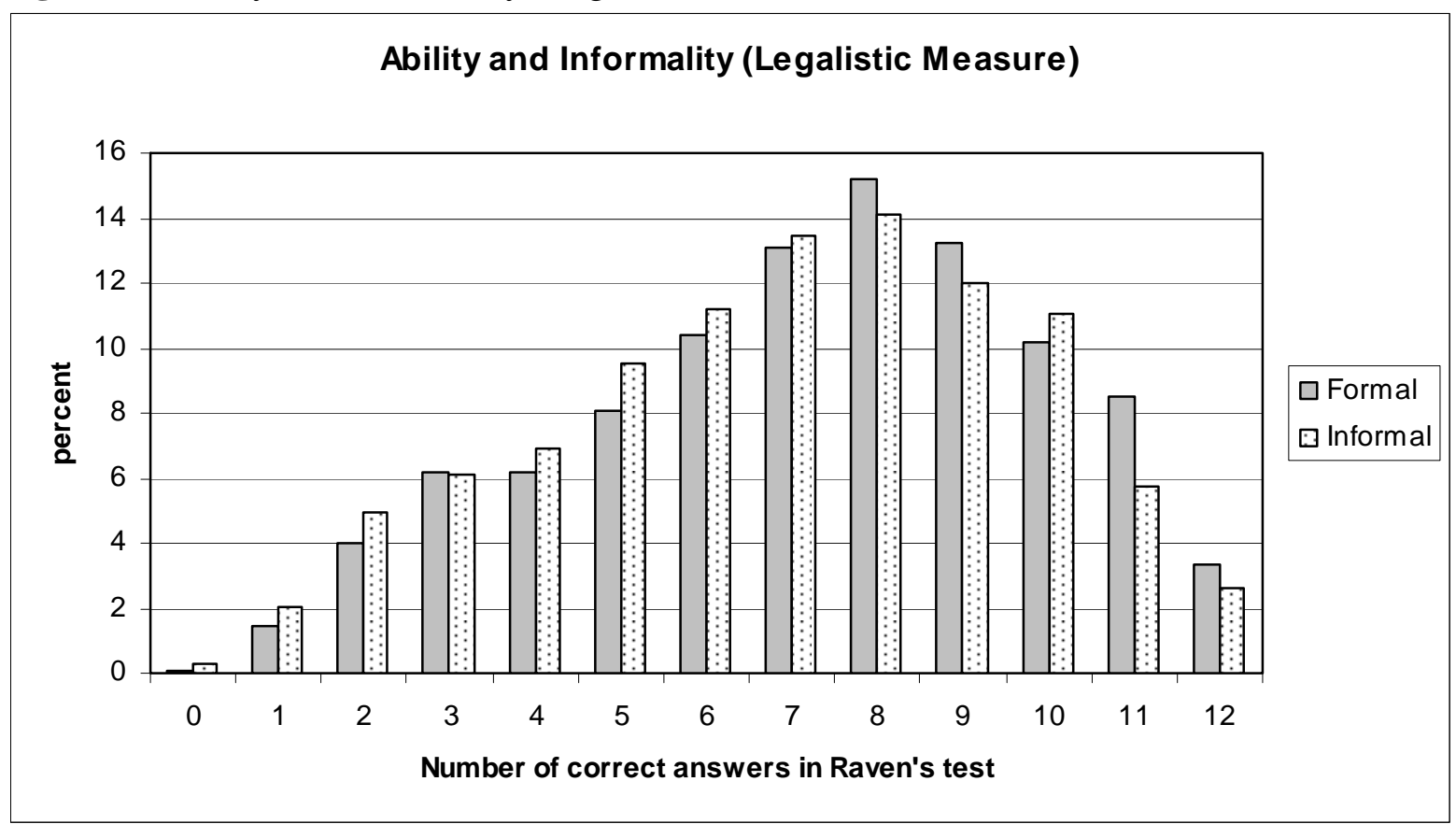

